\title{
Mutations in C-KIT exon 11 in canine cutaneous mast cell tumors
}

\author{
Rafael T Neto, Didir Q Cagnini, Renée L Amorim \\ From São Paulo Advanced School of Comparative Oncology \\ Águas de São Pedro, Brazil. 30 September - 6 October 2012
}

\section{Background}

The $c-K I T$ proto-oncogene encodes the receptor tyrosine kinase KIT, which has been shown to play important roles in the cellular maturation, survival, proliferation, and migration of several cell types including mast cells. Mast cell tumors (MCTs) are the most common cutaneous tumor in the dog. MCTs exhibit wide variation in biological behavior. KIT mutations and aberrant KIT expression have been identified in canine MCTs. Unlike human mastocytosis patients, in which point mutations primarily occur in the kinase domain of KIT, internal tandem duplications (ITD) have been identified in the juxtamembrane domain of KIT in canine MCTs. Among several KIT mutations identified, an ITD in exon 11 has been analyzed most consistently and is significantly associated with malignant behaviour of affected tumors. The goal of this pilot study was to describe ITD KIT mutation in six high grade MTCs and four low grade MCTs.

\section{Materials and methods}

PCR amplification mutational analysis of KIT was performed using a primer pair for C-KIT exon 11, forward primer 5'CCATGTATGAAGTACAGTGGAAG-3' and reverse primer 5'-GTTCCCTAAAGTCATTGTTACA CG-3'. PCR products were analyzed by $1.5 \%$ agarose gel electrophoresis and visualized with $S_{Y B R}{ }^{\circledR}$ Safe DNA Gel Stain. Two of six high grade MCTs (2/6) had ITD KIT mutations. All of these tumors had aberrant diffuse cytoplasmic c-KIT (CD117) localization by immunohistochemistry.

\footnotetext{
* Correspondence: renee@fmvz.unesp.br Department of Clinical Veterinary Medicine, School of Veterinary Medicine and Animal Sciences, Universidade Estadual Paulista (UNESP), Botucatu, SP, Brazil
}

(c) 2013 Neto et al; licensee BioMed Central Ltd. This is an Open Access article distributed under the terms of the Creative Commons Attribution License (http://creativecommons.org/licenses/by/2.0), which permits unrestricted use, distribution, and reproduction in any medium, provided the original work is properly cited.

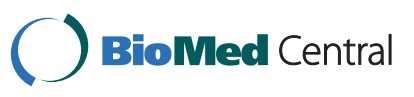

None of low grade tumors 4/4 had ITD KIT mutations, and of these tumors only one (1/4) had aberrant c-KIT immunostaining. Internal tandem duplication of KIT exon 11 mutation was associated with high grade tumors and aberrant C-KIT localization by immunohistochemistry in canine MCTs.

\section{Financial support FAPESP.}

Published: 4 April 2013

\section{doi:10.1186/1753-6561-7-S2-P56}

Cite this article as: Neto et al:: Mutations in C-KIT exon 11 in canine cutaneous mast cell tumors. BMC Proceedings 2013 7(Suppl 2):P56.

\author{
Submit your next manuscript to BioMed Central \\ and take full advantage of: \\ - Convenient online submission \\ - Thorough peer review \\ - No space constraints or color figure charges \\ - Immediate publication on acceptance \\ - Inclusion in PubMed, CAS, Scopus and Google Scholar \\ - Research which is freely available for redistribution \\ Submit your manuscript at \\ www.biomedcentral.com/submit
}

